MATEC Web of Conferences 6, 01006 (2013)

DOI: $10.1051 /$ matecconf $/ 20130601006$

(C) Owned by the authors, published by EDP Sciences, 2013

\title{
Effect of load on thermal spalling of reinforced concrete containing various mineral admixtures
}

\author{
Abdul Rahim ${ }^{1}$, Umesh Kr. Sharma ${ }^{2}$, K. Murugesan ${ }^{3}$ and P. Arora ${ }^{4}$ \\ ${ }^{1}$ Research Scholar, Dept. of Civil Engineering, IIT Roorkee, Roorkee, India \\ ${ }^{2}$ Associate Professor, Dept. of Civil Engineering, IIT Roorkee, Roorkee, India \\ ${ }^{3}$ Associate Professor, Dept. of Mech. \& Ind. Engineering, IIT Roorkee, Roorkee, India \\ ${ }^{4}$ Scientific officer, Reactor Safety Division, BARC, Mumbai, India
}

\begin{abstract}
The present experimental program was planned to investigate the effect of type of mineral admixture, pre-load and the presence of confining reinforcement on the spalling behaviour of heated high performance concrete (HPC). Reinforced concrete cylindrical short columns were cast and exposed to four different target temperatures. A compressive preload equal to $25 \%$ of the ultimate load capacity of column was maintained on the specimens during heating and cooling. The test results mainly focus on the influence of above said variables on spalling behaviour of reinforced HPC columns. Interesting observations have been made in the paper on the subject matter of the workshop.
\end{abstract}

\section{INTRODUCTION}

Various novel types of pozzolanic admixtures namely, silica fume, fly ash, ground granulated blast furnace slag (GGBFS), rice husk and metakaolin are being commonly used for making numerous types of high performance or high strength concretes. It is now well established that inclusion of such mineral admixtures result in to improvements in various mechanical properties as well as durability of concrete. The application of high performance concrete is well accepted in construction industry as a construction material for variety of infrastructural projects. Generally, the concrete is believed to be an excellent fire-proofing material. The previous studies show that inclusion of mineral admixtures in concrete mix improves residual fire performance of concrete [1]. Some other investigations show that the addition of pozzolanic admixture boosts the detrimental thermal effects (such as spalling) [2]. A review of the existing literature shows that the behaviour of HPC is more sensitive to high temperature conditions and the inclusion of mineral admixtures enhances the chances of temperature induced spalling [3, 4]. The spalling of high performance or high strength concrete is influenced by several parameters, such as compressive strength, reduced porosity due to modified dense micro-structure, rapid pore pressure building-up due to presence of moisture and less inter connected pores, differential thermal expansion between constituents and cement paste matrix, high thermal gradients due to rapid heating, section size and shape, external stress and restraint etc. [5-7].

The existing literature indicates that most of the earlier investigations related to fire induced spalling of concrete were undertaken on small scale cubes, un-reinforced and reinforced cylinders or prisms without any pre-load $[4,8,9]$. The performance of concrete containing different mineral admixtures and exposed to elevated temperatures occurring during fire has not been investigated conclusively. In real fire situations, the columns experience permanent loads (self load and service load) from upper floors and concurrently thermal loading in case of buildings subjected to fire. The test data on spalling behaviour of loaded reinforced concrete containing various types of mineral admixtures is very scarce [7]. Further,

This is an Open Access article distributed under the terms of the Creative Commons Attribution License 2.0, which permits unrestricted use, distribution, and reproduction in any medium, provided the original work is properly cited. 
Table 1. Mix proportions of various HPC mixes.

\begin{tabular}{|c|c|c|c|c|c|c|c|c|}
\hline \multirow{2}{*}{$\begin{array}{c}\text { HPC } \\
\text { Mixes }\end{array}$} & \multirow{2}{*}{$\begin{array}{l}\text { Water } \\
\left(\mathrm{kg} / \mathrm{m}^{3}\right)\end{array}$} & \multirow{2}{*}{$\begin{array}{l}\text { Cement } \\
\left(\mathrm{kg} / \mathrm{m}^{3}\right)\end{array}$} & \multirow{2}{*}{$\begin{array}{c}\text { Pozzolana } \\
\left(\mathbf{k g} / \mathbf{m}^{3}\right)\end{array}$} & \multirow{2}{*}{$\begin{array}{c}\text { HRWRA } \\
\left(\mathbf{L} / \mathbf{m}^{3}\right)\end{array}$} & \multicolumn{2}{|c|}{$\begin{array}{c}\text { Aggregate } \\
\left(\mathbf{k g} / \mathbf{m}^{3}\right)\end{array}$} & \multicolumn{2}{|c|}{$\begin{array}{c}\text { Comp. strength } \\
f_{\text {ck }}(\mathrm{MPa})\end{array}$} \\
\hline & & & & & Fine & Coarse & 28 days & 90 days \\
\hline Control & 154.34 & 524.96 & 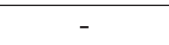 & 3.53 & 654.19 & 1031.56 & 73.90 & 83.34 \\
\hline Fly ash & 152.50 & 434.45 & 152.41 & 5.59 & 627.05 & 1031.56 & 76.03 & 87.02 \\
\hline Silica fume & 154.33 & 446.19 & 101.60 & 3.30 & 597.35 & 1031.56 & 72.69 & 93.59 \\
\hline GGBFS & 155.12 & 380.14 & 254.01 & 2.36 & 649.24 & 1031.56 & 73.93 & 85.12 \\
\hline
\end{tabular}

the literature shows that, the unconfined silica fume high strength concrete (HSC) columns suffered spalling, while none of the confined HSC columns spalled [10-12]. Thus, the present experimental investigation were planned to explore the spalling behaviour of confined HPC short columns under pre-loaded condition and made with different types of mineral admixtures.

\section{EXPERIMENTAL PROGRAM}

\subsection{Material properties}

Three pozzolanic high performance concretes (HPCs) and one non-pozzolanic control HPC mix were used in this study. The test specimens were cast using ordinary Portland cement (OPC), fine aggregate, coarse aggregate, mineral admixtures (silica fume, fly ash and GGBFS), super plasticizer, tap water and steel bars. The above constituent materials of concrete were tested for required properties and proportioned before starting the key operations of the experimental investigation. The commercially available silica fume of grade $920 \mathrm{U}$ and indigenously available fly ash and GGBFS were used as mineral admixtures. The naturally available river sand was used as fine aggregate. Locally available siliceous type crushed aggregate of $12.5 \mathrm{~mm}$ nominal size was used as coarse aggregate. A commercially available high range water reducing admixture based on modified poly-carboxylic either (PCE) polymer with solid content of $9.2 \%$ was used to prepare the various concrete mixes for the required workability. Both sand and coarse aggregates were used in saturated and surface dry (SSD) conditions for preparing the mixes. A slump of 150-180 mm was maintained in all the mixes. The confined column specimens were reinforced with 6 numbers of $8 \mathrm{~mm}$ dia longitudinal steel bars and the lateral ties were at the spacing of $42 \mathrm{~mm}$. The details of HPC mix proportions along with 28 days and 90 days compressive strengths are given in Table 1.

\subsection{Test specimens}

A total of 108 numbers of cylindrical specimens were cast in this study. The cylindrical specimens of size $150 \mathrm{~mm}$ diameter and $450 \mathrm{~mm}$ in height were cast and heated to four different target temperatures namely $200^{\circ} \mathrm{C}, 400{ }^{\circ} \mathrm{C}, 600^{\circ} \mathrm{C}$ and $800^{\circ} \mathrm{C}$. The whole casting work was conducted under the laboratory conditions. The details of specimens with type of mix, load level (stress) and target temperature are given in the Table 2. For each test variable investigated, three specimens were cast in order to get the average of three results. The first letter in the specimen tag indicates the different pozzolanic admixture used to prepare the high performance concrete, the second letter indicates preload maintained during execution of heating. The last letter shows the temperature of exposure. The designation 0 indicates the specimens tested under room temperature, 2 for $200^{\circ} \mathrm{C}$ and so on. The day after the casting, the specimen were demoulded, marked and submerged in the fresh water for curing. The water curing lasted for 28 days, after that the specimens were kept in the laboratory hall in ambient conditions for another 56 days. 
IWCS 2013

Table 2. Details and spalling trends of confined high performance concrete cylindrical test specimens.

\begin{tabular}{|c|c|c|c|c|c|c|}
\hline Mixes & $\begin{array}{l}\text { Test method } \\
\text { method }\end{array}$ & $\begin{array}{l}\text { Room Temp. } \\
\text { Temp. }\end{array}$ & $200^{\circ} \mathrm{C}$ & $400{ }^{\circ} \mathrm{C}$ & $600{ }^{\circ} \mathrm{C}$ & $800^{\circ} \mathrm{C}$ \\
\hline \multirow{6}{*}{ Control HPC } & \multirow{3}{*}{$\begin{array}{l}\text { Without } \\
\text { preloaded }\end{array}$} & CUST0-1 & CUST2-1 & CUST4-1 & CUST6-1* & CUST8-1 \\
\hline & & CUST0-2 & CUST2-2 & CUST4-2 & CUST6-2 & CUST8-2 \\
\hline & & CUST0-3 & CUST2-3 & CUST4-3 & CUST6-3* & CUST8-3 \\
\hline & \multirow{3}{*}{ preloaded } & & CST2-1 & CST4-1 & CST6-1* & CST8-1* \\
\hline & & & CST2-2 & CST4-2 & CST6-2 & CST8-2* \\
\hline & & & CST2-3 & CST4-3 & CST6-3* & CST8-3 \\
\hline \multirow{6}{*}{ Fly ash HPC } & \multirow{3}{*}{$\begin{array}{l}\text { Without } \\
\text { preloaded }\end{array}$} & FUST0-1 & FUST2-1 & \begin{tabular}{|l|} 
FUST4-1 \\
\end{tabular} & FUST6-1* & FUST8-1 \\
\hline & & CUST0-2 & FUST2-2 & FUST4-2 & FUST6-2* & FUST8-2* \\
\hline & & CUST0-3 & FUST2-3 & FUST4-3 & FUST6-3 & FUST8-3* \\
\hline & \multirow{3}{*}{ preloaded } & & FST2-1 & FST4-1 & FST6-1* & FST8-1* \\
\hline & & & FST2-2 & FST4-2 & FST6-2* & FST8-2* \\
\hline & & & FST2-3 & FST4-3 & FST6-3* & FST8-3* \\
\hline \multirow{6}{*}{$\begin{array}{l}\text { Silica Fume } \\
\text { HPC }\end{array}$} & \multirow{3}{*}{$\begin{array}{l}\text { Without } \\
\text { preloaded }\end{array}$} & SUST0-1 & SUST2-1 & SUST4-1 & SUST6-1* & SUST8-1* \\
\hline & & SUST0-2 & SUST2-2 & \begin{tabular}{|l} 
SUST4-2 \\
\end{tabular} & SUST6-2 & SUST8-2* \\
\hline & & SUST0-3 & SUST2-3 & SUST4-3 & SUST6-3 & SUST8-3* \\
\hline & \multirow{3}{*}{ preloaded } & & SST2-1 & SST4-1* & SST6-1* & SST8-1* \\
\hline & & & SST2-2 & SST4-2 & SST6-2* & SST8-2* \\
\hline & & & SST2-3 & SST4-3 & SST6-3* & SST8-3* \\
\hline \multirow{6}{*}{ GGBFS HPC } & \multirow{3}{*}{$\begin{array}{l}\text { Without } \\
\text { preloaded }\end{array}$} & GUST0-1 & GUST2-1 & GUST4-1 & GUST6-1 & GUST8-1 \\
\hline & & GUST0-2 & GUST2-2 & GUST4-2 & GUST6-2 & GUST8-2: \\
\hline & & GUST0-3 & GUST2-3 & GUST4-3 & GUST6-3 & GUST8-3 \\
\hline & \multirow{3}{*}{ preloaded } & & GST2-1 & GST4-1 & GST6-1* & GST8-1* \\
\hline & & & GST2-2 & GST4-2 & GST6-2* & GST8-2* \\
\hline & & & GST2-3 & GST4-3 & GST6-3* & GST8-3* \\
\hline
\end{tabular}

* Indicates the sample observed expolsive spalling during thermal loading.

\section{LOADING ARRANGEMENT DURING HEATING}

Specially constructed reaction frame with vertical split type programmable electrical muffle furnace was used to apply the mechanical load and simultaneous heating to the specimens (Fig. 1). The high temperature furnace had a maximum operating temperature of $1000^{\circ} \mathrm{C}$ and the heating was controlled by microprocessor based temperature controller. The available heating zone was $210 \mathrm{~mm}$ diameter $\times 450 \mathrm{~mm}$ height with the capacity to accommodate single specimen at a time in the furnace. A stainless steel square mesh was loosely wrapped on the specimens to avoid undesirable damage to the unprotected heating zone of furnace refractory materials in the event of spalling.

The test specimens were exposed to four different target temperatures ranging from $200^{\circ} \mathrm{C}$ to $800{ }^{\circ} \mathrm{C}$ after completion of 90 days of ageing. The heating rate was maintained at $5^{\circ} \mathrm{C} / \mathrm{min}$. Each target temperature was maintained for two hours to attain a thermal steady state condition. About $25 \%$ of the average ultimate load capacity of unheated columns was applied on preloaded test specimens. Prior to heating, the test specimen was erected in the furnace then the concentric axial load was applied gradually up to the required load level. The preload was applied approximately 15 minutes before the start of fire test and the load was sustained till the end of the test (i.e. for complete heating and cooling cycle of approximately 24 hours duration). The imposed load was kept throughout the test and no additional load was applied during the test. 


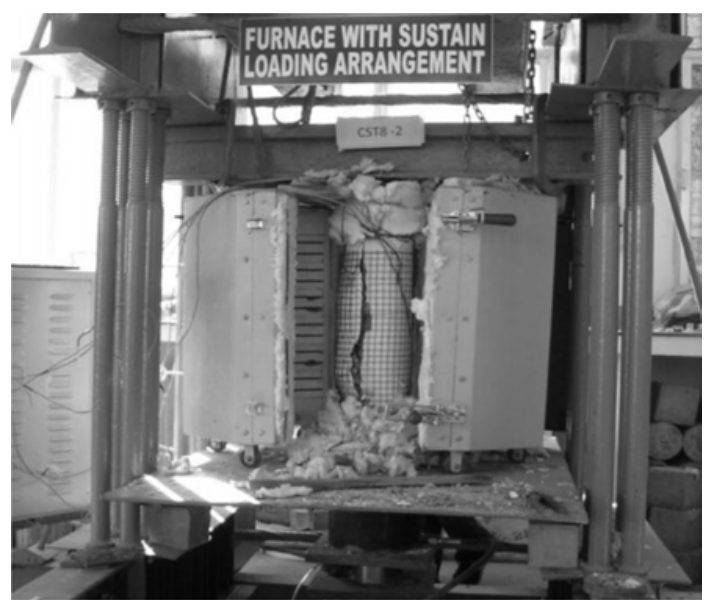

Figure 1. Set-up of furnace with sustained loading arrangement.

\section{THERMAL RESPONSE AND LOAD INDUCED SPALLING}

The Table 2 shows the test matrix of incidences of explosive spalling during the heating. Table 3 provides the relevant details of the spalled specimens. The time of spalling, temperatures and axial load level at the time of spalling of the specimens are presented. Generally, the severity of spalling of concrete is evaluated on the basis of specimen weight loss due to spalling. The criterion used to assess degree of concrete spalling is the ratio of weight of concrete lost due to spalling to weight of the specimen before testing. Following this criterion, the degree of spalling was also evaluated and the data is shown in Table 3. In the spalled specimens, the spalling was observed only in terms of cover spalling either partially or fully up to the reinforcement. The Figure 2 shows a typical explosive thermal spalling in the test specimens of fly ash high performance concrete (FUST6, FST6, FUST8 and FST8). It appears that the explosive spalling of the test specimens occurred by separation of the cover concrete from the reinforced core. It can be seen that, the unloaded specimens showed minor type of spalling but the preloaded specimens showed higher degree of spalling with complete crushing and separation of cover. It may be mentioned here that though the number of specimens spalled were maximum in silica fume HPC, the degree of spalling was slightly higher in fly ash HPC specimens.

Up to $400^{\circ} \mathrm{C}$, no spalling of concrete was observed in all types of HPC specimens, except one preloaded cylindrical specimen, SST4, whose cover spalled. The analysis of the furnace data (Table 3) shows that the event of spalling was explosive in nature and occurred at approximately 117 minutes after the start of the test. The test results also disclosed that the temperature history at the surface and centre of the specimen was $249.5^{\circ} \mathrm{C}$ and $357^{\circ} \mathrm{C}$ and the load on the column was $462.5 \mathrm{kN}$ at the time of spalling.

Further rise of target temperature to $600{ }^{\circ} \mathrm{C}$ and $800{ }^{\circ} \mathrm{C}$ caused spalling in most of the various types of HPC specimens of both series (preloaded and without preloaded). It can be noted from Table 2 that all the preloaded specimens of three pozzolanic HPCs spalled explosively during heating to $600^{\circ} \mathrm{C}$ and $800^{\circ} \mathrm{C}$. The results presented in Table 3 indicate that, the spalling of cover concrete occurred between 91 to 103 minutes in $600{ }^{\circ} \mathrm{C}$ specimens while, the same happened at 89 to 129 minutes for $800{ }^{\circ} \mathrm{C}$. The results also show that at $800^{\circ} \mathrm{C}$, the silica fume HPC specimens had taken shorter time duration to spall compared to other concretes. The non-preloaded specimens exposed to $600^{\circ} \mathrm{C}$ and $800{ }^{\circ} \mathrm{C}$ temperatures indicated less spalling. While all the specimens of preloaded pozzolanic HPC specimens spalled when heated to $600^{\circ} \mathrm{C}$ and $800^{\circ} \mathrm{C}$, only few such specimens of corresponding series of without preload specimens spalled. 
IWCS 2013

Table 3. Characterization of spalling of confined HPC test specimens.

\begin{tabular}{|c|c|c|c|c|c|c|c|c|c|}
\hline \multirow[b]{2}{*}{$\sum$} & \multirow[b]{2}{*}{$\begin{array}{c}\text { Test } \\
\text { method }\end{array}$} & \multirow[b]{2}{*}{ Specimens } & \multirow{2}{*}{$\begin{array}{c}\text { Time at } \\
\text { spalling } \\
\text { (minutes) }\end{array}$} & \multicolumn{2}{|c|}{$\begin{array}{c}\text { Temperature } \\
\left({ }^{\circ} \mathbf{C}\right)\end{array}$} & \multicolumn{2}{|c|}{$\begin{array}{c}\text { Pre load }(\mathbf{k N}) \\
\left(0.25^{*} \mathbf{f}_{\text {room temp }}\right)\end{array}$} & \multirow[b]{2}{*}{$\begin{array}{c}\text { Degree of } \\
\text { spalling }(\%)\end{array}$} & \multirow{2}{*}{$\begin{array}{c}\text { Residual } \\
\text { load } \\
\text { capacity } \\
\text { ratio }(k N)\end{array}$} \\
\hline & & & & surface & centre & $\begin{array}{c}\text { at } \\
\text { beginning }\end{array}$ & $\begin{array}{c}\text { at } \\
\text { spalling }\end{array}$ & & \\
\hline \multirow{6}{*}{ 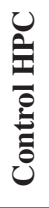 } & \multirow{2}{*}{$\begin{array}{c}\text { Without } \\
\text { preloaded }\end{array}$} & CUST6-1* & 98 & 481.8 & 241.7 & - & - & 8.40 & 0.57 \\
\hline & & CUST6-3* & 85 & 401.4 & 183.5 & - & - & 6.09 & 0.64 \\
\hline & \multirow{4}{*}{ preloaded } & CST6-1* & 109 & 503.4 & 215.7 & 402.35 & 434.4 & 26.67 & 0.77 \\
\hline & & CST6-3* & 107 & 511.2 & 206.7 & 401.85 & 436.9 & 19.06 & 0.78 \\
\hline & & CST8-1* & 118 & 499.1 & 213.5 & 403.8 & 442.8 & 25.11 & 0.28 \\
\hline & & CST8-2* & 103 & 502.3 & 211.3 & 402.69 & 438.5 & 15.89 & 0.48 \\
\hline \multirow{10}{*}{$\begin{array}{l}0 \\
\frac{1}{2} \\
\frac{2}{\sigma} \\
\frac{2}{2}\end{array}$} & \multirow{4}{*}{$\begin{array}{l}\text { Without } \\
\text { preloaded }\end{array}$} & FUST6-1* & 100 & 463.5 & 227.5 & - & - & 8.84 & 0.69 \\
\hline & & FUST6-2* & 102 & 469.8 & 205 & - & - & 9.38 & 0.66 \\
\hline & & FUST8-2* & 101 & 486.9 & 201.6 & - & - & 13.78 & 0.50 \\
\hline & & FUST8-3* & 98 & 470.6 & 197.9 & - & - & 14.20 & 0.43 \\
\hline & \multirow{6}{*}{ preloaded } & FST6-1* & 109 & 467.7 & 199.5 & 448.6 & 486.2 & 21.81 & 0.75 \\
\hline & & FST6-2* & 98 & 455.9 & 204.8 & 449.8 & 485.3 & 22.98 & 0.78 \\
\hline & & FST6-3* & 110 & 491 & $193.9^{\circ}$ & 449.2 & 484.0 & 11.51 & 0.81 \\
\hline & & FST8-1* & 89 & 486.0 & 191.8 & 449.2 & 476.0 & 31.62 & 0.26 \\
\hline & & FST8-2* & 109 & 494.5 & 219.3 & 451.2 & 476.9 & 30.66 & 0.25 \\
\hline & & FST8-3* & 107 & 495.1 & 219.0 & 449.5 & 478.0 & 16.28 & 0.29 \\
\hline \multirow{11}{*}{ 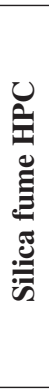 } & \multirow{4}{*}{$\begin{array}{l}\text { Without } \\
\text { preloaded }\end{array}$} & SUST6-1* & 93 & 399.4 & 162.6 & - & - & 17.11 & 0.51 \\
\hline & & SUST8-1* & 92 & 458.4 & 175.5 & - & - & 11.26 & 0.33 \\
\hline & & SUST8-2* & 90 & 454.5 & 169.4 & - & - & 6.17 & 0.32 \\
\hline & & SUST8-3* & 82 & 410.3 & 172.7 & - & - & 10.80 & 0.38 \\
\hline & \multirow{7}{*}{ preloaded } & SST4-1* & 117 & 357 & 249.5 & 433.6 & 462.5 & 23.17 & 0.74 \\
\hline & & SST6-1* & 90 & 448.2 & 204.9 & 433.5 & 458.53 & 18.01 & 0.58 \\
\hline & & SST6-2* & 93 & 453.8 & 208.5 & 431.5 & 464.3 & 22.03 & 0.64 \\
\hline & & SST6-3* & 97 & 447.3 & 202.3 & 433.9 & 453.3 & 20.56 & 0.61 \\
\hline & & SST8-1* & 119 & 488.1 & 222.8 & 434.0 & 453.4 & 23.90 & 0.29 \\
\hline & & SST8-2* & 129 & 484.9 & 233.2 & 433.6 & 466.0 & 22.90 & 0.38 \\
\hline & & SST8-3* & 122 & 486.3 & 229.3 & 434.3 & 460.8 & 20.48 & 0.38 \\
\hline \multirow{8}{*}{ 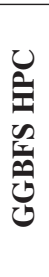 } & \multirow{2}{*}{$\begin{array}{c}\text { Without } \\
\text { Preloaded }\end{array}$} & GUST8-2* & 100 & 461.0 & 215.6 & - & - & 6.22 & 0.38 \\
\hline & & GUST8-3* & 98 & 455.7 & 224.8 & - & - & 10.44 & 0.46 \\
\hline & \multirow{6}{*}{ preloaded } & GST6-1* & 103 & 405.5 & 177 & 422.05 & 453.0 & 8.37 & 0.80 \\
\hline & & GST6-2* & 91 & 408.2 & 174.2 & 421.1 & 449.4 & 38.81 & 0.81 \\
\hline & & GST6-3* & 91 & 414.9 & 175.7 & 419.0 & 445.4 & 24.57 & 0.85 \\
\hline & & GST8-1* & 93 & 496.5 & 218.3 & 420.3 & 452.6 & 24.49 & 0.30 \\
\hline & & GST8-2* & 100 & 485.3 & 232 & 419.2 & 438.6 & 25.50 & 0.31 \\
\hline & & GST8-3* & 107 & 479.2 & 215.7 & 421.6 & 456.7 & 14.60 & 0.34 \\
\hline
\end{tabular}

The residual load capacity of various test specimens was also measured and results are shown in Table 3. The preloaded specimens showed higher load carrying capacity under the residual test conditions compared with non preloaded specimens. In case of specimens exposed to temperatures up to $600{ }^{\circ} \mathrm{C}$. This is the beneficial influence of loading, which place the material into compression and inhibits the developments of cracks. However, there was significant strength reduction in all types of confined concrete specimens as the temperature increased to $800^{\circ} \mathrm{C}$. In such specimens the residual compressive strength was comparable in both preloaded and without preloaded specimens. The previous literature shows that while unconfined high strength concrete spalls explosively $[8,9]$ the confinement of concrete prevents spalling of concrete [13]. The results of present study show that confining reinforcement could save only the core concrete. The cover concrete of confined concrete specimens spalled irrespective of confinement. Even the cover spalling would reduce the carrying capacity of concrete columns as the contribution of cover is no more available. Further studies are underway in this regard. 
MATEC Web of Conferences

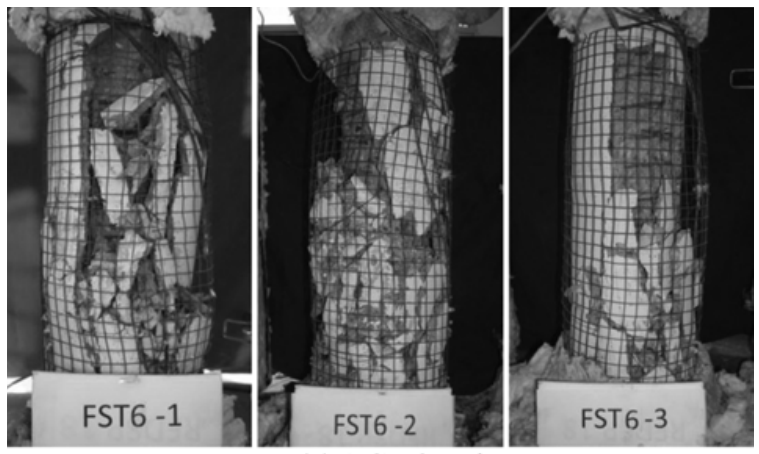

(a) FST6 series

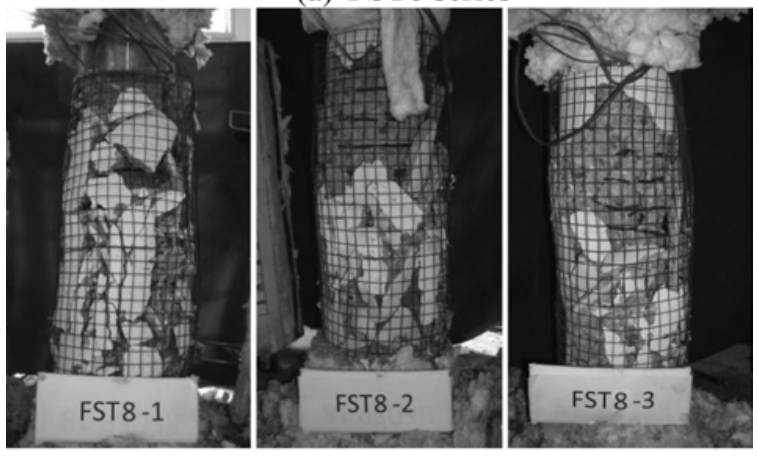

(b) FST8 series

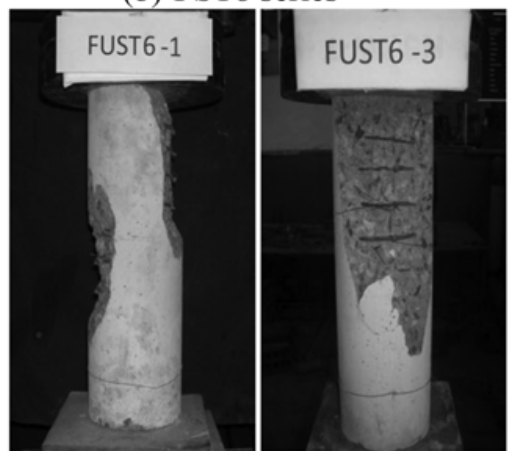

(c) FUST6 series

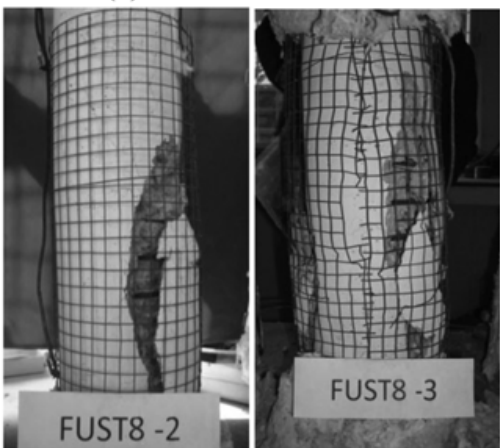

(d) FUST8 series

Figure 2. (a)-(d) Typical Spalling of confind fly ash HPC specimens. 


\section{CONCLUSIONS}

This study reports the thermal performance of various pozzolanic high performance concretes subjected to elevated temperatures. Within the scope of the present investigation, the following conclusions may be drawn:

- The detrimental effects of temperature on the spalling behaviour of pozzolanic and non- pozzolanic HPC do not matter much up to a temperature of $400^{\circ} \mathrm{C}$. An exposure at higher temperatures such as $600{ }^{\circ} \mathrm{C}$ and $800^{\circ} \mathrm{C}$ increases the thermal spalling of HPC irrespective of the type of pozzolana. The silica fume HPC is more vulnerable to spalling than fly ash and GGBFS HPC. Non-pozzolanic HPC is least influenced by spalling.

- The presence of axial load on HPC during heating results in to more severe spalling compared to the HPC specimens with no load during heating.

- The explosive spalling was observed between 82 to 129 minutes of start of heating for all HPC mixes. The surface temperature at the time of spalling varied from $479.2^{\circ} \mathrm{C}$ to $511.2{ }^{\circ} \mathrm{C}$ and the core temperature varied from 196.7 to $241.7^{\circ} \mathrm{C}$.

- Though, the severe explosive spalling of core is saved by providing the confining reinforcement for high performance concrete columns the cover is still liable to be spalled.

The authors thankfully acknowledge the financial support received from Board of Research in Nuclear Sciences (BRNS)-MUMBAI for conducting this study.

\section{References}

[1] Poon C. S., Azhar S., Anson M., and Wong Y., Comparison of the strength and durability performance of normal- and high-strength Pozzolanic concretes at elevated temperatures, Cement Concrete Research, 31, 1291-1300, 2001.

[2] Phan L. T., Carino N. J., Review of mechanical properties of HSC at elevated temperature, Journal of Materials in Civil Engineering, ASCE, 10(1), 58-64, 1998.

[3] Lawson L. J., Phan L.T., Davis F., Mechanical properties of high performance concrete after exposure to elevated temperatures, NISTR 6475, 1-35, 2000.

[4] Kodur V. K. R., Dwaikat M., Fire induced spalling in reinforced concrete beams, Structures and Buildings, ICE Proceedings, 165, (SB7), 347-359, 2012.

[5] Kodur K. V. R., Sultan M. A., Structural behaviour of high performance concrete columns exposed to fire, International Symposium on High Performance and Reactive Power Concrete, 217-232, 1998.

[6] Khoury G. A., Anderberg Y., Concrete spalling review. Fire Safety Design, 1-60, 2000.

[7] Ali F. A., O’Connor D., Abu-Tair A., Explosive spalling of high strength concrete columns in fire, Magazine of Concrete Research, 53(3), 197-204, 2001.

[8] Kodur, V. K., McGrath, R., Effect of silica fume and lateral confinement on fire endurance of high strength concrete columns, Canadian Journal of Civil Engineering, 33(1), 93-102, (2006).

[9] Kodur V. K. R., and Dwaikat M. B., Effect of fire induced spalling on the response of reinforced concrete beams, International Journal of Concrete Structural Materials, 71-81, 2008.

[10] Wu B., Su X. P. Li, H Yuan J., Effect of High Temperature on Residual Mechanical Properties of Confined and Unconfined High-Strength Concrete, ACI Materials Journal, 99 (4), pp. 399-407, 2002. 


\section{MATEC Web of Conferences}

[11] Sharma U. K., Zaidi K. A., and Bhandari N. M., Residual Compressive Stress-Strain Relationship for Concrete Subjected to Elevated Temperatures, Journal of Structural Fire Engineering, 3(4), 327-350, 2012.

[12] Zaidi S. K. A. Residual compressive behaviour of confined concrete subjected to elevated temperatures, Ph.D Thesis, Department of civil Engineering, Indian Institute of Technology Roorkee, Roorkee, India, pp. 219, 2011.

[13] Kodur V. K. R. and Phan L., Critical factors governing the fire performance of high strength concrete system, Fire Safety Journal, 42, 482-488, 2007. 